\title{
Rajan Gurukkal on Indian Higher Education: Quality, Excellence in Neoliberal Times
}

\author{
Rolla Das*
}

Rajan Gurukkal is a leading social scientist and is currently the Sundararajan Visiting Professor at Centre for Contemporary Studies, Indian Institute of Science. He has been the former Vice Chancellor, M. G. University, Kottayam, Kerala. An avid reader, critical theorist and a prolific writer, he has authored several monographs, research articles and has been actively engaged with several projects in association with UGC, the Ford Foundation to name a few. His research interests explore the historiographic dimensions and dialectical processes involving the state and society. He can be reached at rgurukkal@gmail.com.

\section{Conversation with Rajan Gurukkal: An introduction}

While the interview is rooted in the context of quality in higher education, the conversation explores and unpacks several, interweaving relations between education, society and state. Often, in the discourses of higher education in India, we notice an absence, a deliberate obscuring or at best, a fleeting attention being paid towards the role of the socio-economic situation and political environment on the current education situation. Professor Gurukkal, in this conversation, exposes the role of corporations, capitalistic globalisation, lack of governmental regulations as primary factors that shape the current educational scenario. He stresses on the importance of rethinking the aim of quality education in India: a shift from the conceptualisation of

*Christ University, Bengaluru, India; rolla.das@christuniversity.in 
'managerial efficiency' as the purpose of education to envisioning an educational environment that instils a sense of liberal, critical consciousness, which philosophers argue to be of utmost importance for the education of our students. This, he aims, we can achieve through societally embedded pedagogies and curricula, which instead of commodifying, would bring about a sense of education for the public good and make students socially aware.

\section{${ }^{1} R D$ : What do you think about the quality context in Indian higher education?}

${ }^{2} R$ G: As you know, India's poor quality education is a belief so entrenched today that we almost hesitate to question it. All of us are obsessed with quality but rarely do we ask what quality means, for we feel that its attributes are self-evident and universal. There is no universally accepted definition of quality teaching or learning. Teaching/learning science does point to certain ways, means, measures and parameters of effective learning. Cognitive science does differentiate levels of learning but without privileging one level over the other. In philosophy of education, quality of teaching/ learning is subjective, unstable and differing in time and space. What is to be learnt or what competencies are to be acquired seem to differ from period to period, for each socio-economic system has its own needs.

\section{$R D$ : How do you characterise the present socio-economic system of the country?}

R G: We have to review the demographic situation first and then examine the socio-economic context. Our total population is about 127 crore and almost $40 \%$ of it are in the age-group of 18-22. Indeed a big thing to have such a huge population of youth, but the country should be able to nurture them competent to reap the advantages of demographic dividend. The International Labour Organization (ILO) anticipates in India the availability of 116 million youth in the age group of 20-24 by 2020, which will be 22 million more compared to the aggregate youth population in

\footnotetext{
${ }^{1}$ Rolla Das [R D]

2 Rajan Gurukkal [R G]
} 
China. Dependency ratio in the country is going to be extremely advantageous, for the average national age by 2020 will be 29 years as distinguished from those of developed countries like America (40 years), Japan (46 years), and Europe (47 years). By then India will have over $60 \%$ of the aggregate population in the age group of 15 to 59 years.

$R D$ : What precaution do you expect that the Government should take by way of resource allocation, specifically in the context of the country's decision to do away with the five-year plan?

$R$ G: The demographic situation shows that National policy of resource allocation for higher education should be wiser and more insightful than what it used to be. Since XI Plan onwards, the policy has been incrementally that of privatisation and commercialisation under the excuse of the state's financial inability amidst its unavoidably huge revenue expenditure for national defence, industrial and urban infra-structural development. A ponderous paradox is the extravagant indulgence of the nation in heavy urbanisation involving enormous cost while it laments about economic crunch. It is strange that the distinctly advantageous demographic conditions excite no seriousness in the national planners about the urgency of treating higher education as a very crucial sector of investment, which they have been foolishly disregarding as a field of heavy expenditure.

$R D$ : What kind of socio-economic structure, you think, is likely to persist preventing us from taking the demographic dividends?

$R$ G: The current socio-economic situation of India is that of a nation of unevenly developed people of different ethnic, caste, religious, and regional identities and of glaring economic inequalities with a lion share of the population lying below the poverty line. It is one of competitive co-existence of diverse groups, mainly of the middle class, with a relatively low percentage of higher income groups who are placed above and a number of tribal people, scheduled castes, and people of other backward communities placed below. 


\section{$R D$ : What about the situation of the middleclass?}

$R$ G: The upper middle class people with upper caste domination have greater access and control of economic resources, advanced agricultural and marketing expertise, superior technical capabilities based on higher education and training, wide exposure, sophisticated information and political information. As a result, they involve in a variety of economic enterprises, hold positions of political power, high salaried white-collar jobs in government, quasi-government and private sectors, and control the exchange of goods and services. They are the main actors in government that belong to the middleclass both in theory and in practice. Overall, the upper middleclass people are more security conscious and status sensitive than their lower counterpart is. Many of them have a long tradition of higher social status and ranking based both on the economy as well as on caste. Obsessively non-dependent and nuclear family centred, they yearn to maintain a closure of selfcontained life of the neighbours' envy. Highly pretentious and characteristically opaque, they never share problems with others. Naturally, these people constitute the most anxious and tense stratum of the contemporary society.

\section{$R D$ : What about the plight of access against the situation of increasing inequalities?}

$R G$ : Estimates based on the data generated by the $71^{\text {st }}$ and $70^{\text {th }}$ rounds of National Sample Survey show that socio-economic inequalities have been substantially increasing both in the urban as well as rural areas of the country. The economically well off groups are able to incrementally access quality higher education, acquire expertise for higher remuneration jobs or develop entrepreneurial capabilities and thrive while the lower income groups run into debt traps by accessing expensive higher education. Both at the state and national levels the rich are becoming richer and the poor, poorer by struggling to access the benefit of healthcare and higher education. A major reason for this has been the gradual withdrawal of the state from and the steady growth of privatisation and commercialisation of these vital sectors. It has been clearly shown how glaring has been the interstate inequalities in the sectors of healthcare and higher education. 


\section{$R D$ : Could you elaborate on the concerns regarding GER?}

$R$ G: It is a fact that the GER of the youth in the Country's Higher Education sector is abysmally poor and the difference between the total strength of the enrolled and that of the eligible is frustratingly big. Most of the eligible but not enrolled, are both economically and academically backward. The present GER in higher education is around 12 per cent (world average 23.2 per cent, developed nations 54.6 per cent, Asian countries 22 per cent) and the government wants to increase this to 21 per cent by 2017 . There is an interim GER target of 15 per cent by 2011-12, for which the enrolments in universities/ colleges need to be substantially raised to 21 million students. The government estimates that the share of enrolments of private, unaided higher education institutions will be around 51 per cent. It is obvious that the government alone will not be able to achieve GER target and will require public partnership, private investment, and participation of foreign institutions to achieve this ambitious goal.

\section{$R D$ : Is shortage of the number of institutions and the insufficient intake capacity of institutions a valid argument?}

$R G$ : The widely and repeatedly aired cause of low GER is the insufficiency of the number of higher educational institutions. Academic backwardness is generally assigned to low standard and poor quality of education, ignoring the explicit issue of the convergence of economic backwardness and academic low quality. The main cause that the ministry of human resource development has approved is shortage in the number of higher educational institutions of standard and quality and the various national educational reforms under way are postulated avowedly to address the issue. The ministry's decision to open up as many new Colleges and universities as possible is a direct response to the alleged shortage in the number of higher educational institutions.

$R D$ : How do you react to the repeated complaints of the state about its financial inability to support higher education?

$R$ G: It has been an oft-repeated excuse that the Government cannot afford to fund and maintain too many higher educational institutions all by itself, thanks to the constraint of school education being its 'primary effort area', and hence enhanced participation of 
the private sector has to be promoted. We owe the number of unaided institutions, which has been steadily rising since the beginning of nineties to the liberal policy promoting enhanced private sector participation. During the last five years, their mushrooming has been phenomenal. This has caused a steady decline in the standard of education due to the non-compliance of the national criteria of quality assurance. State patronage of commercialisation and privatisation has made meaningful functioning of statutory regulatory bodies extremely difficult. Market competition has not led to quality enhancement in the country's education sector, because of the national shortage of the eligible clientele. It is essential to devise a set of effective measures of socio-economic preparation for enhancing the number of youth capable of accessing higher education.

\section{$R D$ : You think that it is the socio-economic scenario that decides the whole thing. Can you elaborate a bit on the actual process of the working of it?}

$R$ G: Socio-economic system has to be understood in the critical political economy perspective. We are implicated by the global economy and its pressure to introduce various neo-liberal reforms. Ever since the signing of GATTS agreement by the nation, education has become legally a profiteering private enterprise. According to the provisions provided for in the agreement, an educational institution charging a fee, even if it is a meagre sum, shall be treated under the category of trade. As a result, knowledge is regarded as a commercial item licensed for exchange across the present day world. Education has ceased to be a public good of socio-cultural use-value, once knowledge began to be produced and transmitted as an object of exchange for accumulating profit. Commercialisation of education is a worldwide phenomenon today. In developing countries, its consequences are more intense. It has created serious access disparity with respect to opportunities of knowledge acquisition in India. 
$R D$ : Knowledge economy discussed too much these days is not often understood as the latest version of capitalism and as the dominant global economy with enormous impact on higher education. Can you explain it in some detail?

$R$ G: Knowledge Economy, technically known as Techno-capitalism due to its heavy dependence on technology, is the dominant economy of the present day world. It was Andrew Feenberg who first discussed this as the latest version of capitalism way back in 1991. Although he did not name it as Techno-capitalism, he had noticed its technology dependent nature. New Knowledge is both commodity and capital in this phase of capitalism. Needless to mention that the role of research in the economy that counts GDP in terms of gross technology product (GTP) and gross science product (GSP) is decisive. It has opened up an era of intellectual assets often called intangible assets relating primarily to technology. Intangible or intellectual assets also constitute both commodity and capital in the economy. This has put discovery science under intense pressure to inevitably open up or at least point to its transformation into innovation science. It is Louis Suarez-villa in his work of 2000, who characterised at length the heavy dependence of the economy on technological innovation and explained how it accounted for naming this phase of capitalism as techno-capitalism. He has examined and theorised the spawning new forms of corporate power and organisation of major implications for the twenty-first century higher education, in his study.

\section{$R D$ : What does commoditisation of knowledge mean? Can you explain the process and implications briefly?}

$R$ G: Knowledge Economy turns knowledge into a commodity that acquires multiple forms, each of which differently priced on the basis of its market demand. Let the beneficiary pay for acquiring knowledge is the neoliberal approach to education. Knowledge, as the philosophic means to a better life, is contrasted with knowledge as a commodity under capitalism. Commoditisation of knowledge is a process of transformation of knowledge into an explicit, standardised, codified, and priced object of exchange value. Commoditisation is conversion of results of human labour into commodities to be transacted by the market. It has been a process 
integral to the growth of capitalist economy. In a strategic process it could facilitate the conversion of social products of use-value into objects of exchange value, namely commodities in the market, and make it uncritically accepted by all with a sense of obsessive devotion. It is this phenomenon that Karl Marx called as 'commodity fetishism' - an ideological veil of capitalism within which we have today a whole discipline called economics constituted. Progress of commoditisation of knowledge, detaching it from the (user) person and making it an independent economic entity, has given rise to the phenomenon called capital fetishism from which, arose the practice of owning and controlling knowledge as intellectual property. Easily distributed via global communication networks, knowledge with authorial ownership began to become an important source of personalised profit, necessitating special legal protection.

$R$ D: How do the corporate houses directly involve in the production and transaction of knowledge as commodity. How do they transform new knowledge into both commodity and capital?

$R$ G: It was Michael Perelman who first analysed the corporate Houses' processes of production and transaction of new knowledge, both as commodity and capital, in his book of 2004 . Under Techno-capitalism, 'New knowledge' and 'Creativity' become the most valuable resources, as much as what raw materials and factory labour used to be under industrial capitalism. This accounts for the global recognition of Patents and Intellectual Property Rights under International Laws. Perelman shows how corporate houses and corporate establishments resort to various clever ways and means for the appropriation of research outcomes through new relations of power. According to him, it becomes a reckless confiscation of the intangibles - 'New Knowledge,' 'Creativity' and 'Innovativeness' of the researchers. Corporate houses have globally established a powerful techno-military complex of electronic sophistication and juridical devices for confiscating the intangible assets and gaining monopolistic control over them through the purchase of Patents and IPR. He argues that the exploitation of intellectual assets under techno-capitalism is far more extensive than what it had been about the exploitation of raw materials under industrial capitalism. Suarez-Villa has traced that 50 
the emergence of techno-capitalism towards the process of globalisation and the growth of techno-capitalist corporations. Trading in the innovative knowledge and creativity well known today as intangible assets, it generates four-fifth of the total global returns today. Corporate houses controlling experimentalist establishments are compelling scientists to transform their discoveries into inventions. Forming into corporate houses, it has evolved a new form of industrial organisation too. Suarez-Villa shows how new areas of science-tech researches such as genomics, synthetic bioengineering, bioinformatics, bio-pharmacology, nanotech sensors and transmitters, and so on are being expanded by them.

\section{$R D$ : How do politicians and bureaucrats in the country respond to this global scenario? Are they really aware of all this and go about evolving appropriate policy measures?}

$R$ G: Politicians largely draw blank about all this. A few bureaucrats know it, but they are in the hands of the corporate houses. They conceive higher education only as a sector of expenditure rather than investment. Therefore, the nation is not able to set apart even 3\% of the GDP for higher education for dearth of money. At the same time several actors in the government go recklessly extravagant and there is no financial discipline in the working of the Government. Naturally, production of new knowledge, which is highly sophisticated and enormously expensive, is extremely rare in any of the fields of modern sciences. Even traditional Indian knowledge systems are new meadows only for foreigners who take patents in them. Indians, uninitiated in traditional knowledge language of their country, draw blank about its scientific dimensions. Corporate Houses are seeking to enhance monopolistic control through Patents and IPR over the country's traditional knowledge as a major source of production of new knowledge. As regards the higher education sector, the state has become determined to streamline all institutions and practices with a view to quicken the process of expansion of education as an industry with more and more private players. This has necessitated liberalising of the statutory restrictions administered through the University Grants Commission and its Councils. It has been a matter of consensus among the neoliberal higher education 
reformers that there should be a single regulator at the national level to serve the purpose of liberalisation, saving time and money. In the process, the state power itself is getting privatised in the form of sale of public credits or bidding of the job of recovering government loans or the task of crime investigation with the consequences like mafia rule, drug abuse, and terrorism. Major excuses for the state measures for the privatisation of its functions are the lack of concern of the beneficiary public, irresponsibility of the public servants, incapability of the public sector institutions, bureaucratic inefficiency in government, bribery and other forms of corruption. All this allows the capitalist minority to loot the public revenue under the connivance of the state under the pretext of one development reform or the other. This phase is called crony capitalism, for which there are many instances in India.

\section{$R D:$ How do the bureaucrats see the quality question?}

$R$ G: Quality assurance is largely projected by bureaucrats as a question of managerial efficiency and hence their recommendations invariably emphasise measures of privatisation and commercialisation, which guarantee standard through competition. This approach has always precluded the possibility of analysing what quality means and how it develops. There is no dependence on specialised knowledge in the related fields like the science of pedagogy, cognitive science and neurology of learning for diagnosing the problems and resolving them. Hence, the reports of such committees are managerial implementation packages with little academic insights into the problem. Their real objectives purposely hushed up and the stated ones altogether bogus, the remedial prescriptions remain unfounded and self-contradictory.

\section{$R D$ : What is the reason for the obsessive talk about quality and excellence?}

$R$ G: The present day clamour for quality higher education is not genuine. The reports and recommendations resonate similar trends. All the conversations, I feel, are to prepare an appropriate environment and legitimacy for commercialisation of higher education, by devaluing the public higher education sector and spreading the hope that the competitive private sector will render 
quality education plausible. It is not accidental that none of the recommendations helps quality assurance. Electronic sophistication of learning through ICT or multi-media education alone cannot ensure quality learning. Unless the content is carefully and profoundly designed, media will act as the message. Media can be a stronger ideological veil effectively masking the truth. What then gets promoted in the name of quality learning will be an altogether mechanical and alienating process that divests learning of its critical power. Quality learning according to Techno-capitalism is the one that results in the attainment of competencies essential for effective participation in it. Only a relatively small number of learners can be successful in innovative learning for neurological, genetic, economic, social, cultural and political reasons. Nevertheless, its present number can certainly be enhanced considerably through economic, socio-cultural and political preparations on the one side and the promotion of real learning. It is a self-consciously realist learning totally bereft of any alienating, compelling forces independent of the learner. Actually, it is selfdirected, personalised learning.

\section{$R D$ : Will learning in ICT environment help the self-directed and personalised learning that you mention?}

$R$ G: Smart classrooms will not help. Smart campus might serve the purpose. We have to open up in the campus, several specific points of electronic sophistication for accessing knowledge. It is designing outside space into self-directed learner space. In other words, it means creation of the learner ecosystem.

\section{$R D$ : What is this learner ecosystem? Can you elaborate a bit?}

$R$ G: An ecosystem denotes a natural system in which its constituent elements are in symbiotic relationships. Learning ecosystem connotes a conducive learning environment with all its integral elements organically linked with one another. As in the case of natural ecosystem, learning ecosystem also refers to symbiotic relationships amongst constituents like the natural space, institutional structure, infrastructure and the academic community, wherein learning takes place. In the existing learning environment, the structure and function of natural space are not consciously designed to be in harmony with the process of learning. Therefore, 
the task is to design the natural space of the University campus as imbued with elements integral to learning, so that learning happens naturally, informally and effectively. A campus should consist of ecological niches for learners to congregate in small groups, engage fruitfully in their learning through collective exercises of knowing, seeing, thinking, deliberating, doing/experimenting, discovering, innovating, and growing intellectually. It should also have personalised study spots within the built structures as well as outside, which can be called the learner ecosystem.

\section{$R D$ : How do you define quality in teaching and learning?}

$R$ G: Quality higher education is the one that renders deeper knowledge plausible through the process. It is scientific knowledge distinguished from information that is primary in nature. Information is factual in nature whereas knowledge is conceptual, procedural, meta-cognitive and distinct for its intellectual depth. It is inherently critical. Who decides what knowledge is and what understanding means, although quite important for any critical thinker, this interrogation seldom occurs to the general public. Such critical thinking is largely not part of their habit, even though they form one of the major democratic populace of the world. We owe this to our education. In fact, critical consciousness is almost alien to our pedagogy at all levels. One is supposed to be acquiring critical consciousness in the process of higher education; but it hardly happens today. Even the critical attitude of a liberal pragmatic kind, which spontaneously comes up in any educated citizen of democratic values, passions and ethical postulates, is uncommon today. Actually, a person of higher learning is normally inspired by the radical critical stance based on the fire of moral truth. In the process of higher learning we experience the subversive dynamic of deeper knowledge, which is inherent to it.

\section{$R D$ : In your opinion, what ought to be quality higher education today?}

$R$ G: Quality higher education today should be the one that generates critical consciousness essential to understand the implications of knowledge economy that is triggered by the 
capitalist globalisation. Critical faculty helps students understand that the growing global importance of intangibles like new knowledge and technological innovativeness is widening the inequalities between nations and aggravating brain-drain. It makes clear to them that the techno-military-corporate complex is growing dominant and becoming ever more intrusive and rapacious through its control over technology and innovation. Naturally, criticality is intolerable to Corporate Establishments. There is their pressure on the state to impose on all the higher education institutions a militaristic discipline. Techno-capitalism requires an apathetic, unaffected, regimented and uncritical contingent of experts of micro specialisation precluding holistic perspective. What the dominant economy needs is a well disciplined, workaholic and apolitical youth trained in various skills. Whatever education that produces this robotic youth is quality education or innovative education to it. For it quality education is the one that would check as far as possible the production of ethical, political subjects of critical consciousness.

\section{$R D$ : Finally, what is it that most of us in the field of higher education either fail to realise or rather are complacent about?}

$R G$ : We often fail to realise that it is the principal actors in the dominant economic system, who decide what knowledge is and how we should acquire it. In capitalist economy, science and technology constitute the knowledge of critical function, forming the foundation of capitalist forces of production and the principal source of accumulation. Capitalism recognises science and technology its knowledge, for it is amenable to profitable application. Other forms of knowledge are being co-opted, incorporated, subordinated, subjected, marginalised or destroyed depending upon their levels of amenability to profitable application.

\section{References}

Feenberg, A. (1991). Critical theory of technology. New York: Oxford University Press.

Marx, K. (1974). The fetishism of commodities and the secret thereof (Vol. I, Part I and 4). In Capital. English Version, Moscow: Progress Publishers. 
Perelman, M. (2004). Steal this idea: Intellectual property rights and the corporate confiscation of creativity. London: Palgrave Macmillan Publishers.

Suarez-Villa, L. (2009). Globalization and techno-capitalism: The political economy of corporate power and technological domination. Burlington VT: Ashgate Publishers.

Suarez-Villa, L. 2012. Techno-capitalism: A critical perspective on technological innovation and corporatism. Philadelphia: Temple University Press. 